Jurnal Pemberdayaan: Publikasi Hasil Pengabdian kepada Masyarakat

Vol. 4, No. 3, Desember 2020, Hal. 355-360

ISSN: 2580-2569; e-ISSN: 2656-0542

DOI: https://doi.org/10.12928/jp.v4i3.2849

\title{
Pelatihan Learning Management System Menggunakan Schoology pada Guru di Gugus Ki Hajar Dewantara Kabupaten Semarang
}

\author{
Sri Sukamta, Ulfah Mediaty Arief, Subiyanto, Tatyantoro Andrasto, Fitria Ekarini, Agung \\ Adi Firdaus, Achmad Rifaldi \\ Jurusan Teknik Elektro, Universitas Negeri Semarang \\ Email: ssukamta2014@mail.unnes.ac.id
}

\begin{abstract}
ABSTRAK
Pada masa mendatang penerapan teknologi internet di bidang pendidikan dan pelatihan akan sangat dibutuhkan dalam rangka peningkatan kualitas dan pemerataan layanan pendidikan. Sehingga diperlukan solusi yang tepat dan cepat dalam mengatasi berbagai masalah yang berkaitan dengan mutu pendidikan. Melalui e-learning, pendidikan jarak jauh yang bergantung pada jarak dan waktu untuk pelaksanaan pendidikan dan pelatihan akan dapat diatasi, sehingga diperlukan penggunaan suatu media learning management system. Kegiatan pelatihan learning management system pada guru di Gugus Ki Hajar Dewantoro Kabupaten Semarang telah dilaksanakan pada 18-25 Juli 2020 menggunakan media Zoom Meeting dengan materi pengenalan sampai dengan mempraktikkan pembelajaran dengan LMS Schoology. Kegiatan pembukaan dan penutupan juga dilaksanakan secara langsung di SDN Sugihan 02 melalui perwakilan. Pelatihan dilakukan oleh tim pengabdian Jurusan Teknik Elektro Universitas Negeri Semarang yang terdiri dari lima orang dosen dan dua orang mahasiswa. Dilakukan evaluasi dengan memberikan pre test dan post test. Hasil pre test menyimpulkan peserta yang kebanyakan berstatus sebagai guru, masih belum menerapkan learning management system dan belum mengetahui Schoology dengan rata-rata skor sebesar 70\% dan 73\%. Dalam segi kebermanfaatan, evaluasi juga dilakukan melalui beberapa aspek diantaranya adalah: 1) aspek keterbantuan, 2) ketertarikan pendidik dan siswa, 3) kemudahan, dan 4) fleksibilitas. Hasil evaluasi yang telah dilaksanakan terkait manfaat yang dirasakan saat menggunakan media Schoology sebagai LMS mendapatkan skor 79\%-85\% untuk setiap aspeknya. Hal tersebut menyimpulkan, ketertarikan dan kebermanfaatan Schoology sebagai LMS dalam pembelajaran cukup tinggi.
\end{abstract}

Kata kunci: Pelatihan, Learning Management System, Schoology

\begin{abstract}
In the future, the application of internet technology in education and training will be urgently needed in order to improve the quality and distribution of education services. So that we need the right and fast solutions in overcoming various problems related to the quality of education. Through e-learning, distance education which depends on distance and time for the implementation of education and training will be overcome, so it is necessary to use a media learning management system. Learning management system training activities for teachers in the Ki Hajar Dewantoro Cluster, Semarang Regency, were held on 18-25 July 2020 using Zoom Meeting media with introductory materials to practicing learning with LMS Schoology. The opening and closing were also carried out directly at SDN Sugihan 02 through representatives. The training was conducted by a service team from the Department of Electrical Engineering, Semarang State University, which consisted of five lecturers and two students. Evaluation was carried out by providing a pre test and post test. The pre-test results concluded that the participants, most of whom were teachers, still had not implemented a learning management system and did not know Schoology with an average score of $70 \%$ and $73 \%$. In terms of usefulness, evaluation is also carried out through several aspects including: 1) aspects of assistance, 2) interest of educators and students, 3) convenience, and 4) flexibility. The results of evaluations that have been carried out regarding the benefits felt when using Schoology media as an LMS get a score of 79\% -85\% for each aspect. This concludes, the interest and usefulness of Schoology as an LMS in learning is quite high.
\end{abstract}

Keywords: Training, Learning Management System, Schoology 


\section{PENDAHULUAN}

Perkembangan teknologi jaringan internet mengalami kemajuan yang sangat pesat. Kegiatan dengan metode konvensional perlahan-lahan mulai mengalami pergeseran, karena dianggap kurang efektif dibandingkan kegiatan modern yang memanfaatkan teknologi internet dan komputer. Perkembangan komputer dan jaringan tidak sebatas pada pembuatan, pengiriman dan penyimpanan data saja, melainkan memungkinkan kita untuk berinteraksi secara langsung bahkan pada jarak yang jauh sekalipun (Ngafifi, 2014).

Hal tersebut berdampak pada berbagai aspek dalam kehidupan tak terkecuali pada bidang pendidikan. Electronic learning (E-Learning) kini semakin dikenal sebagai salah satu cara untuk mengatasi masalah pendidikan, baik di negara-negara maju maupun di negara yang sedang berkembang. E-learning merupakan pembelajaran yang menggunakan perangkat elektronik sebagai alat bantu, dalam pelaksanaan e-learning biasanya dilengkapi dengan media text, audio, video atau kombinasi dari ketiganya (Choiroh, 2020). Salah satu kelebihan sistem pembelajaran dalam jaringan (daring) adalah pembelajaran dilakukan dari jarak jauh. Kita tidak perlu datang ke kelas dan bertatap muka dengan guru atau dosen setiap hari. Dengan menggunakan fasilitas teknologi digital dan koneksi internet, pembelajaran dapat dilakukan dimana saja dan kapan saja tanpa terkendala jarak (Holil, 2020). Contoh pembelajaran daring berbasis web yang sedang booming saat ini adalah Ruang Guru dan Zenius. Atas dasar tersebut e-learning mempunyai potensi yang sangat besar di Indonesia.

Di masa datang penerapan teknologi internet di bidang pendidikan dan pelatihan akan sangat dibutuhkan dalam rangka peningkatan kualitas dan pemerataan layanan pendidikan, terutama di Indonesia yang wilayahnya tersebar di berbagai daerah yang sangat berjauhan. Sehingga diperlukan solusi yang tepat dan cepat dalam mengatasi berbagai masalah yang berkaitan dengan mutu pendidikan, serta upaya untuk merealisiasikan pemerataan layanan pendidikan sebagaimana yang diamanatkan oleh undang-undang. Melalui e-learning, pendidikan jarak jauh yang bergantung pada jarak dan waktu untuk pelaksanaan pendidikan dan pelatihan akan dapat diatasi (Adawi, 2008).

Learning Management System (LMS) adalah aplikasi sofware atau teknologi berbasis web yang digunakan untuk merencanakan, mengimplementasikan dan menilai proses pembelajaran (Muhammad Rozi Yerusalem, Desain dan Implementasi Sistem Pembelajaran Jarak Jauh Di Program Studi Sistem Komputer , 2015). Menurut pendapat Kustandi dalam Friansah (2020), LMS adalah suatu perangkat lunak yang digunakan untuk membuat materi pembelajaran secara online berbasiskan web dan mengelola kegiatan pembelajaran siswa serta kegiatan evaluasi. Saat ini ada beberapa LMS yang ditawarkan secara gratis diantaranya Edmodo dan Schoology. Salah satu LMS yang menarik dan berkembang saat ini adalah Schoology. Schoology merupakan situs LMS sekolah, lembaga pendidikan tinggi serta perusahaan/institusi yang dapat membuat berbagi konten serta mengelolanya dengan baik. Tahun 2007 Jeremhy Friedman, Tim Trinidad, dan Ryang Hwang merancang Schoology. Penggunanya mencapai 7,5 juta di 60.000 sekolah pada 200 negara tercatat sejak November 2014 (Drajat Friansah, 2020). Dengan adanya schoology, materi pembelajaran mudah untuk diakses. seperti layaknya belajar di kelas. Fungsi dari laman web ini juga sama dengan yang lain seperti Blackboard dan WebCT yang di dalamnya memberikan penawaran guru untuk membantu dalam memahami pelajaran. Disamping itu, schoology juga memberikan akses kepada orang tua untuk memantau perkembangan dan kemajuan belajar anaknya di sekolah.

Berdasarkan hasil wawancaran dengan guru yang tergabung dalam Gugus Ki Hajar Dewantara Kabupaten Semarang, didapatkan bahwa e-learning belum banyak diterapkan oleh guru sekolah dasar, karena kebanyakan guru menganggap metode ini rumit dan membutuhkan sarana dan prasarana yang mahal. Padahal pada kenyataannya, e-learning cukup mudah penggunaannya dan tidak harus menggunakan fasilitas yang tergolong mahal dan harus memiliki website e-learning sendiri. Masalah ini telah dibahas solusinya yang 
merincikan tentang beberapa faktor yang mendukung e-learning sudah cukup layak untuk diaplikasikan di sekolah Indonesia (Suhartono, 2010). Banyak sekolah telah memiliki perangkat komputer, namun hanya digunakan sebagai perangkat administrasi saja. Sudah semakin meratanya jaringan internet di Indonesia, termasuk di Kabupaten Semarang. Selain itu, tersedianya beberapa sistem pendukung e-learning, bahkan sudah banyak yang tersedia dalam bentuk open source atau juga yang gratis seperti LMS Schoology. Berdasarkan uraian permasalahan di atas maka perlu diadakan pelatihan LMS pada guru di Gugus Ki Hajar Dewantoro Kabupaten Semarang.

\section{METODE}

Pelaksanaan pelatihan ini dilakukan secara mixed method antara pelatihan langsung dan daring. Pembukaan dan penutupan secara langsung dilakukan di SDN Sugihan 02 dan diikuti 53 peserta berasal dari guru-guru dan operator di Gugus Ki Hajar Dewantara Kabupaten Semarang. Pelatihan dilakukan selama 7 hari pada tanggal 18 Juli 2020 sampai dengan 25 Juli 2020 menggunakan media Zoom Meeting dengan materi pengenalan sampai dengan mempraktikkan pembelajaran dengan LMS Schoology.

Kegiatan pengabdian kepada masyarakat ini dilaksanakan dalam bentuk pelatihan dengan beberapa tahapan pembelajaran dalam pelatihan sebagai berikut:

1. Tahap Pemberian Undangan dan Sosialisasi

Tahap ini dilakukan melalui kerjasama dan perizinan kepada Gugus Ki Hajar Dewantara oleh Tim Pengabdian Teknik Elketro. Setelah itu dilakukan sosialisasi terkait alat dan bahan yang dibutuhkan selama mengikuti pelatihan dan manfaat yang akan didapatkan selama pelatihan.

2. Tahap Pelatihan.

Pada tahap ini diberikan teori tentang Schoology dengan metode ceramah dan tanya jawab. Pada tahap ini juga dilakukan simulasi atau praktik tentang penggunaan Schoology secara langsung.

3. Tahap Evaluasi.

Evaluasi hasil pelatihan dilakukan melalui pemberian angket dengan media Google Form. Angket terdiri dari pre test dan post test.

\section{HASIL, PEMBAHASAN, DAN DAMPAK Pelaksanaan Pelatihan}

Pelaksanaan kegiatan pelatihan Learning Management System pada guru di Gugus Ki Hajar Dewantara Kabupaten Semarang berlangsung pada 18-25 Juli 2020 menggunakan media Zoom Meeting karena adanya pandemi, sehingga pertemuan secara fisik diminimalisasi. Materi yang diberikan adalah pengenalan Schoology sampai dengan mempraktikkan Schoology sebagai media dalam pembelajaran. Untuk pembukaan dan penutupan, selain dilakukan secara online juga dilaksanakan secara langsung di SDN Sugihan 02 melalui perwakilan tim pengabdian dan perwakilan peserta pelatihan. Pelatihan dilakukan oleh tim pengabdian Jurusan Teknik Elektro Universitas Negeri Semarang yang terdiri dari lima orang dosen dan dua orang mahasiswa dari Jurusan Teknik Elektro.

Pada tahap sosialisasi yaitu pengenalan dan penjelasan agenda yang akan dilakukan. Hal-hal yang harus dipersiapkan peserta peserta antara lain; (1) laptop atau smartphone, (2) internet, (3) web browser, dan (4) akun gmail. Pada hari pertama merupakan pelaksanaan pembukaan, sedangkan hari terakhir adalah pelaksanaan penutupan dan pembagiaan sertifikat. Pembagian penyampaian materi pada pelatihan dirangkum dalam Tabel 1. 
Tabel 1. Pembagian Materi Pelatihan

\begin{tabular}{|c|c|c|}
\hline No & Hari, Tanggal & Materi \\
\hline 1 & Minggu, 19 Juli 2020 & $\begin{array}{l}\text { - } \text { Mendaftar akun di Schoology } \\
\text { - } \quad \text { Sign in di Schoology } \\
\text { - } \text { Mengenali tampilan interface Schoology }\end{array}$ \\
\hline 2 & Senin, 20 Juli 2020 & $\begin{array}{l}\text { - Pembuatan kelas (Course) } \\
\text { - Menambahkan anggota kelas siswa dan } \\
\text { orangtua }\end{array}$ \\
\hline 3 & Selasa, 21 Juli 2020 & $\begin{array}{l}\text { - Menambah bahan pembelajaran (Materials) } \\
\text { - } \quad \text { Memperbarui informasi pada kelas (Update) }\end{array}$ \\
\hline 4 & Rabu, 22 Juli 2020 & $\begin{array}{l}\text { - Membuat ujian atau kuis } \\
\text { - Menggunakan buku penilaian tugas }\end{array}$ \\
\hline 5 & Kamis, 23 Juli 2020 & $\begin{array}{l}\text { - Pengaturan penilaian dan evaluasi } \\
\text { - Kehadiran atau presensi }\end{array}$ \\
\hline
\end{tabular}

Penyampaian materi pelatihan tentang Schoology dilakukan secara bertahap dalam lima hari pada jam 10.00 sampai dengan 13.00. Gambar 1. merupakan dokumentasi pelatihan LMS Schoology yang telah dilaksanakan.

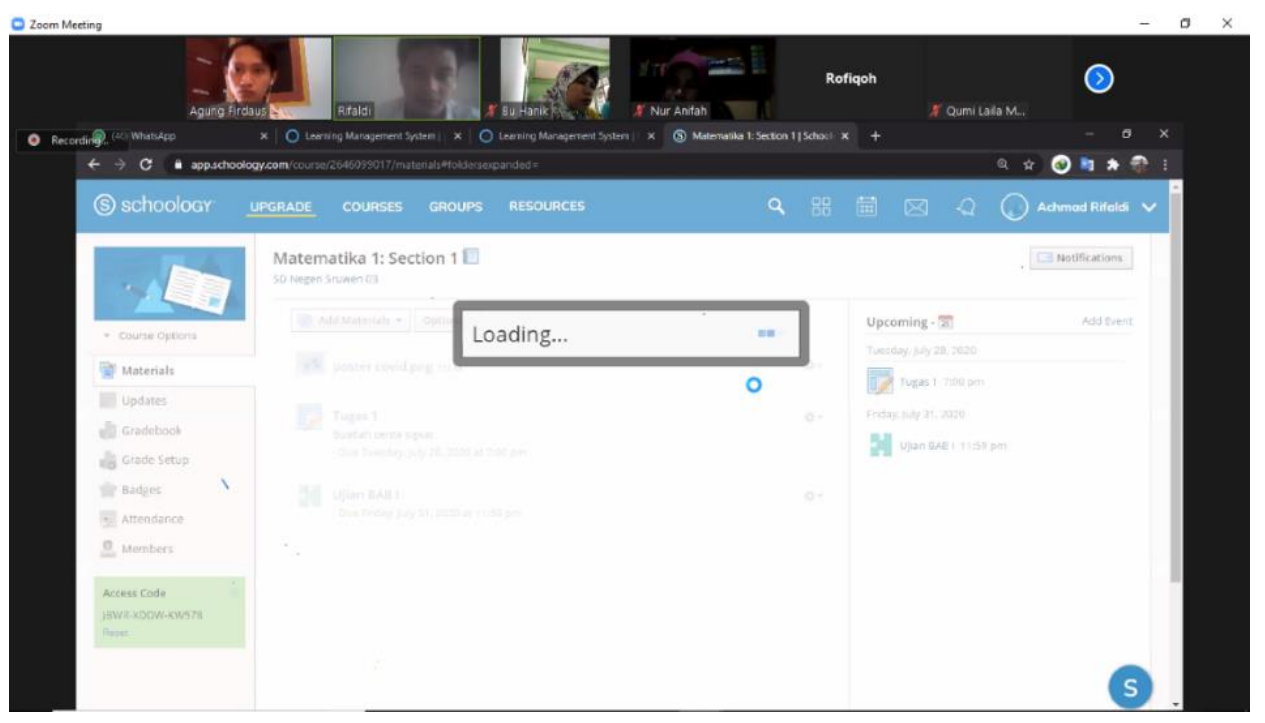

Gambar 1. Dokumentasi Pelatihan yang Dilaksanakan

\section{Evaluasi}

Evaluasi dilaksanakan melalui pemberian angket pre test pada saat sebelum pelatihan dilaksanakan dan post test pada saat setelah pelatihan dilaksanakan. Berdasarkan evaluasi yang telah dilakukan, peserta kebanyakan belum menggunakan learning management system secara online di sekolah masing-masing. Seperti yang ditunjukkan pada Tabel 2 persentase penggunaan learning management system di sekolah.

Tabel 2. Penggunaan Learning Management System di Sekolah

\begin{tabular}{lll}
\hline No & Pengetahuan & Persentase \\
\hline 1 & Sudah & $30 \%$ \\
2 & Belum & $70 \%$ \\
\hline
\end{tabular}


Terdapat 30 persen responden yang sudah menggunakan LMS dengan media yang digunakan adalah Edmodo, Google Form dan Whatsapp. Belum ada yang menggunakan Schoology sebagai LMS di sekolah. Peserta yang kebanyakan berstatus sebagai guru, namun masih banyak yang belum mengetahui Schoology yaitu sebesar $73 \%$ peserta pelatihan. Sedangkan $27 \%$ sudah mengetahui, namun beberapa hanya sebatas tahu dan tidak mengenal secara mendalam menu yang ada di dalam Schoology. Tabel 3 merupakan pengetahuan manajemen pembelajaran dengan Schoology. Berdasarkan keterangan dari peserta pelatihan, kebanyakan siswanya sudah bisa menggunakan handphone walaupun sebagian masih milik orang tua karena mayoritas merupakan guru sekolah dasar.

Tabel 3. Pengetahuan Manajemen Pembelajaran dengan Schoology

\begin{tabular}{lll}
\hline No & Pengetahuan & Persentase \\
\hline 1 & Sudah Mengetahui & $27 \%$ \\
2 & Belum Mengetahui & $73 \%$ \\
\hline
\end{tabular}

Selain pre test, peserta juga diberikan post test menggunakan media Google Form. Aplikasi Schoology terbukti menarik bagi pendidik dan siswa, hal tersebut didasarkan atas penilaian yang diberikan oleh peserta berkaitan dengan ketertarikan dan efisiensi media Schoology dalam pembelajaran, rata-rata sekitar $78 \%$ peserta menilai pembelajaran lebih efisien menggunakan media Schoology. Peserta juga menilai pembelajaran lebih menarik menggunakan Schoology dengan skor $80 \%$ seperti pada Tabel 4.

Tabel 4. Ketertarikan dan Efisiensi Media Schoology dalam Pembelajaran

\begin{tabular}{lll}
\hline No & Aspek & Skor \\
\hline 1 & $\begin{array}{l}\text { Proses pembelajaran lebih efisien } \\
\text { menggunakan LMS Schoology }\end{array}$ & $78 \%$ \\
2 & $\begin{array}{l}\text { Proses pembelajaran lebih menarik } \\
\text { menggunakan LMS Schoology }\end{array}$ & $80 \%$ \\
3 & $\begin{array}{l}\text { Aplikasi Schoology menarik bagi pendidik } \\
\text { dan siswa }\end{array}$ & $78 \%$ \\
\hline
\end{tabular}

Dalam segi kebermanfaatan, evaluasi juga dilakukan melalui beberapa aspek diantaranya adalah: 1) aspek keterbantuan, 2) ketertarikan pendidik dan siswa, 3) kemudahan, dan 4) fleksibilitas. Tabel 5 menunjukkan hasil evaluasi yang telah dilaksanakan terkait manfaat yang dirasakan saat menggunakan media Schoology sebagai LMS dalam pembelajaran.

Tabel 5. Kebermanfaatan Media Schoology dalam Pembelajaran

\begin{tabular}{lll}
\hline No & Aspek & Skor \\
\hline 1 & $\begin{array}{l}\text { Schoology membantu guru dan siswa } \\
\text { mengembangkan ruang diskusi }\end{array}$ & $82 \%$ \\
2 & $\begin{array}{l}\text { Schoology dapat menarik siswa untuk interaktif } \\
\text { dalam proses belajar }\end{array}$ & $81 \%$ \\
3 & $\begin{array}{l}\text { Memudahkan pendidik dalam penyampaian materi } \\
\text { pembelajaran } \\
\text { Memudahkan pengoreksian tugas dan penilaan hasil } \\
\text { belajar siswa }\end{array}$ & $79 \%$ \\
\hline
\end{tabular}




\begin{tabular}{lll}
\hline 5 & $\begin{array}{l}\text { Mengurangi kesalahan dalam pemberian tugas dan } \\
\text { penilaian terhadap siswa }\end{array}$ & $81 \%$ \\
6 & $\begin{array}{l}\text { Schoology lebih fleksibel karena dapat digunakan } \\
\text { kapan saja dan dimana saja }\end{array}$ & $84 \%$ \\
\hline
\end{tabular}

\section{SIMPULAN}

Kegiatan pelatihan Learning Management System pada guru di Gugus Ki Hajar Dewantoro Kabupaten Semarang telah dilaksanakan pada 18-25 Juli 2020 menggunakan media Zoom Meeting dengan materi pengenalan sampai dengan mempraktikkan pembelajaran dengan LMS Schoology. Pembukaan dan penutupan pelatihan telah dilaksanakan secara langsung di SDN Sugihan 02 melalui perwakilan tim pengabdian dan perwakilan peserta pelatihan. Pelatihan dilakukan oleh tim pengabdian Jurusan Teknik Elektro Universitas Negeri Semarang yang terdiri dari lima orang dosen dan dua orang mahasiswa. Dilakukan evaluasi dengan memberikan pre test dan post test. Hasil pre test menyimpulkan Peserta yang kebanyakan berstatus sebagai guru, masih belum menerapkan Learning Management System dan belum mengetahui Schoology dengan rata-rata skor sebesar 70\% dan 73\%. Dalam segi kebermanfaatan, evaluasi juga dilakukan untuk mengukur pengaruh pelatihan yang diberikan melalui beberapa aspek diantaranya adalah: 1) aspek keterbantuan, 2) ketertarikan pendidik dan siswa, 3) kemudahan, dan 4) flesibilitas. Hasil evaluasi yang telah dilaksanakan terkait manfaat yang dirasakan saat menggunakan media Schoology sebagai LMS mendapatkan skor paling rendah $79 \%$ dan tertinggi $85 \%$ untuk setiap aspeknya. Hal tersebut menyimpulkan, peserta pelatihan tertarik dan merasakan manfaat saat menggunakan Schoology sebagai LMS dalam pembelajaran.

\section{DAFTAR PUSTAKA}

Adawi, R. (2008). Pembelajaran Berbasis Elearning. BAHAS O (69TH XXXV). https://doi.org/10.24114/bhs.v0i69TH XXXV.2397.

Choiroh, N. (2020). Efektifitas Pembelajaran Berbasis Daring/ E-Learning Dalam Pandangan Siswa. Retrieved September 8, 2020, from https://iainsurakarta.ac.id/\%EF\%BB\%BFefektifitas-pembelajaran-berbasis-daring-e-learningdalam-pandangan-siswa/

Drajat Friansah, Y. Y. (2020). Pelatihan Learning Management System-Schoologybagi Guru Mgmp Matematika Sma/Smk Kabupaten Musi Rawas. JURNAL CEMERLANG: Pengabdian pada Masyarakat, 184-195.

Holil, A. (2020, 05 31). Kompas.com. Retrieved from Kompas: https://edukasi.kompas.com/read/2020/05/31/172306571/menyiapkan-normal-barupembelajaran-yang-berpihak-pada-siswa-kita?page $=$ all

Muhammad Rozi Yerusalem, A. F. (2015). Desain dan Implementasi Sistem Pembelajaran Jarak Jauh Di Program Studi Sistem Komputer. Jurnal Teknologi dan Sistem Komputer, 481-492.

Muhammad Rozi Yerusalem, A. F. (2015). Desain dan Implementasi Sistem Pembelajaran Jarak Jauh Di Program Studi Sistem Komputer . Jurnal Teknologi dan Sistem Komputer, 481-492.

Ngafifi, M. (2014). Kemajuan Teknologi dan Pola Hidup Manusia. Jurnal Pembangunan Pendidikan: Fondasi dan Aplikasi, 2(1), 33-47.

Suhartono, H. (2010). Survey 2009: Mutu Situs E-Learning Indonesia Masih Sangat Minim. Fakultas Ilmu Komputer, Universitas Indonesia, 80-83. 